\title{
Studi Literatur Perencanaan dan Algoritma Pembentukan DMA (District Metered Area)
}

\author{
Ayu Noer Annisa dan Wahyono Hadi \\ Jurusan Teknik Lingkungan, Fakultas Teknik Sipil dan Perencanaan, Institut Teknologi Sepuluh \\ Nopember (ITS) \\ Jl. Arief Rahman Hakim, Surabaya 60111 Indonesia \\ e-mail:wahyono@enviro.its.ac.id
}

\begin{abstract}
Abstrak - Pembentukan DMA adalah salah satu upaya yang dapat dilakukan untuk menekan tingkat kehilangan air fisik. Suatu kota dapat mempunyai ratusan DMA. DMA merupakan singkatan dari district metered area. Hal tersebut berarti bahwa suatu DMA adalah suatu wilayah atau area yang dibatasi oleh satu atau beberapa meter air dan beberapa valve. Antara satu DMA dan DMA lain tidak mempunyai hubungan. Sehingga, kehilangan air dapat diketahui lebih spesifik untuk masingmasing DMA. Pembacaan meter air pelanggan setiap satu bulan sekali dilakukan bersamaan dengan pembacaan meter air utama yang ada di masing-masing DMA. Akumulasi perhitungan air terjual dari setiap meter air pelanggan seharusnya sama dengan air yang terbaca di meter air induk (meter air DMA). Jika terdapat ketidaksamaan, maka diketahui bahwa terdapat kebocoran di DMA tersebut. Selama ini, perencanaan DMA hanya didasarkan oleh kemampuan teknik dan pengalaman lapangan staf yang berkecimpung dalam merencanakan DMA. Peneliti-peneliti tengah melakukan penelitian mengenai perencanaan DMA menggunakan algoritma. Kemudian hasilnya disimulasikan dan dapat diketahui dampak dari perencanaan DMA itu sebelum DMA diimplementasikan.
\end{abstract}

Kata Kunci- DMA, algoritma, kehilangan air, kebocoran fisik.

\section{PENDAHULUAN}

$\mathrm{I}^{\mathrm{rCC}}$ PCC (2014) memperkirakan bahwa peningkatan suhu menyebabkan terjadinya gelombang panas. Hal tersebut mengakibatkan penguapan akan semakin sering terjadi di beberapa wilayah di dunia. Oleh karena itu, sektor air harus dimanfaatkan sebaik dan seefektif mungkin. Di daerah perkotaan, produktifitas air kurang optimal. Salah satu faktor produktifitas dapat dinilai dari tingkat kehilangan air. Kehilangan air dapat digambarkan sebagai selisih antara air yang didistribusikan dan jumlah air yang dibayar oleh konsumen [1].

Kelangkaan air adalah masalah utama yang melingkupi banyak negara. Hal tersebut menyebabkan perhatian kepada efisiensi dan reliability terhadap air sangat besar disamping harus menjaga kontinuitas ketersediaan air. Sehingga ada fokus utama dilakukan terhadap performansi dari segi operasional sistem. Operasi dan kontrol terhadap distribusi air secara optimal meliputi (1) meminimalkan biaya yang dibutuhkan untuk pemompaan, (2) peraturan mengenai tekanan untuk menghindari kebocoran, dan (3) mengoptimalkan kualitas air minum dengan cara mengurangi waktu tinggal air di dalam pipa/ jaringan [1].

Menurut [2] sebanyak 38,4\% air yang diproduksi oleh PDAM di Indonesia hilang sehingga tidak terbayarkan. Hal ini menyebabkan kerugian sebesar Rp 1,139 Triliun setiap tahunnya. Kehilangan air ini terdiri dari konsumsi resmi tak berekening (1,9\%), kehilangan air komersial (11,5\%) dan kehilangan air fisik $(25 \%)$.

Kunci manajemen kehilangan air dalam pipa distribusi adalah mengidentifikasi faktor-faktor yang mempengaruhi kehilangan, baik fisik maupun non-fisik. Kemudian, strategi dapat disusun untuk mencari solusi sesuai permasalahan yang ada [3]. Sistem distribusi air adalah komponen utama dari infrastruksur sipil dalam hal penyediaan air. Penelitian dalam bidang distribusi air minum mempunyai fokus ke pendekatan menggunakan simulasi, kalibrasi, dan desain optimalisasi dari suatu jaringan [1].

Bagi kebanyakan sistem, tingginya tingkat kehilangan air (non-revenue water/ NRW) terdiri dari kebocoran (kehilangan fisik) dan air yang tidak dapat dibayarkan oleh konsumen (kehilangan komersial) [3]. Kehilangan nonfisik/ komersial dapat dirinci menjadi empat elemen fundamental, ketidakakuratan meter pelanggan, konsumsi tak resmi, kesalahan pembacaan meter, kesalahan penanganan data dan pembukuan. Sedangkan kehilangan fisik dapat terjadi karena; kebocoran pada pipa transmisi, kebocoran pada pipa distribusi, kebocoran pada tempat penampungan air dan luapan kebocoran pada sambungan pipa pelanggan [4].

Terdapat dua macam sistem distribusi, yakni sistem terbuka dan sistem tertutup. Pengelolaan NRW pada sistem terbuka yang dijalankan secara pasif dilakukan hanya ketika kehilangan mulai nampak terlihat atau dilaporkan. Satu pendekatan yang lebih efektif adalah dengan mewujudkan pengelolaan NRW yang aktif [4].

Beberapa sistem distribusi air tidak memiliki DMA dalam sistem manajemennya. Akan tetapi, sistem tersebut akan sukses mengontrol kebocoran jika mempunyai; kualitas infrastruktur yang sangat bagus, biaya perbaikan dan operasi yang rendah, dan tekanan yang stabil. Sehingga, untuk mengurangi kekurangan tersebut sistem distribusi dapat menggunakan DMA sebagai salah satu strategi kebocorannya [5]. Selain itu, [4] juga menyebutkan bahwa pengelolaan NRW yang aktif hanya mungkin dilakukan dengan menggunakan 
zona-zona. Zona-zona merupakan kawasan bermeter (District Metered Area/ DMA) yang harus terisolasi secara hidraulis.

Zonasi pada jaringan sistem distribusi air minum dapat menurunkan tingkat NRW. Penurunan NRW memiliki banyak manfaat, antara lain; tersedianya akses tambahan untuk PDAM dalam bentuk perputaran uang yang dihasilkan sendiri (selfgenerated cash flow), pengurangan sambungan-sambungan ilegal sehingga tercipta keadilan antar para pengguna, meningkatknya layanan pelanggan, dan tersedia peluangpeluang usaha baru [4].

Membentuk serangkaian DMA bukan hanya menargetkan pengurangan NRW tapi juga memperbaiki kondisi aset dan layanan kepada pelanggan dengan; (1) Menjaga umur aset melalui manajemen tekanan, (2) Menjaga kualitas air, dan (3) Memungkinkan pasokan air yang berkesinambungan [4]. Selain itu, pembentukan DMA juga dapat menyederhanakan neraca air dan mengidentifikasi kehilangan air [6].

Pembagian jaringan sistem distribusi menjadi DMA-DMA membagi jaringan-jaringan yang terhubung dan tidak teratur menjadi sub-jaringan yang dapat dikelola dengan lebih baik. Selain itu, pembentukan DMA memerlukan teknik yang efisien. Pembentukan DMA dapat dilakukan dengan menutup valve di pipa jaringan eksisting, membagi jaringan pipa, menambahkan pipa baru, dll. Pembentukan DMA dilakukan secara empirik, berdasarkan pengalaman pihak yang bersangkutan dan sangat sedikit penelitian mengenai hal ini [7]. Meskipun manfaat dari pembentukan DMA sangat banyak, akan tetapi literatur dan penelitian mengenai cara mendesain DMA amat sedikit [8].

\section{METODE PENELITIAN}

Penelitian/ kajian pustaka dilakukan terhadap semua jurnal dan publikasi yang berhubungan dengan sistem jaringan distribusi air minum secara umum, kebocoran, dan algoritma pembentukan DMA. Selain itu, dilakukan juga kajian pustaka terhadap algoritma-algoritma yang digunakan dalam jurnaljurnal yang dikaji oleh peneliti-peneliti. Kajian pustaka ini akan memberitahukan cara merencanakan DMA, dampak pembentukan DMA terhadap sistem distribusi air minum, dan algoritma yang dapat digunakan untuk membentuk DMA.

\section{HASIL DAN PEMBAHASAN}

\section{A. Perencanaan DMA}

Langkah-langkah dalam membentuk DMA pada prinsipnya adalah dengan melakukan langkah-langkah sebagai berikut:

1) Menyiapkan peta jaringan distribusi air minum,

2) Menetapkan kriteria perencanaan/ kriteria desain sambungan rumah dalam DMA,

3) Membentuk DMA sesuai dengan rentang yang telah ditetapkan di langkah-2,

4) Menutup/ membuat valve-valve batas antara satu DMA dengan DMA yang lain,

5) Melakukan pemasangan meter air di titik yang dikehendaki,
1) Mengevaluasi DMA menggunakan salah satu dari indikator resilience index, tekanan, flow deficit index, dan water age,

2) Mengitung volume pekerjaan dan biaya (rencana anggaran biaya/ RAB),

3) Memastikan bahwa aliran valve sudah ditutup dan DMA yang ada sudah terisolasi dengan melakukan uji isolasi (jika langkah 5 tidak terpenuhi, maka harus kembali ke langkah 4),

Langkah uji isolasi pada langkah-4 dan langkah-5 berfungsi untuk memastikan bahwa semua pipa ke dalam dan keluar DMA ditutup atau bermeter. Adapun langkah uji isolasi adalah sebagai berikut:

1) Menutup semua saluran masuk air (inlet) bermeter

2) Memeriksa apakah tekanan air di dalam DMA turun menjadi nol karena air semestinya tidak bisa lagi memasuki wilayah

Jika tekanan tidak turun menjadi nol, ada kemungkinan bahwa ada pipa lain yang memungkinkan air untuk masuk ke kawasan dan oleh karenanya harus diatasi. Setelah DMA selesai dibentuk dan terisolasi, maka DMA dapat dipantau kehilangan air fisik dan non fisiknya.

\section{B. Pengaruh DMA}

Kesuksesan dari implementasi DMA dalam menangani kebocoran ternyata tidak terlepas dari beberapa dampak. Hal ini dikarenakan adanya penutupan beberapa pipa yang menyebabkan konfigurasi dan hidrolika jaringan distribusi air minum menjadi berubah. Performance indices adalah salah satu hal yang dapat menggambarkan kemampuan suatu sistem jaringan distribusi air minum. Pembuatan DMA akan mengakibatkan penurunan kualitas performance indices suatu sistem jaringan distribusi air minum.

Performance indices adalah faktor-faktor yang dapat merepresentasikan jaringan air. Performance indices jaringan air sebelum dan setelah pembentukan DMA dapat berbeda.

Performance indices ini mengukur tekanan air baik tekanan air rata-rata, minimum, maksimum, dan juga standar deviasi tekanan pada setiap node yang dibandingkan dengan resilience index $\mathrm{I}_{\mathrm{R}}$, untuk mengukur kemampuan suatu jaringan distribusi air mampu memenuhi permintaan (demand) dan tekanan di nodes.

$$
I r=\frac{\sum_{i=1}^{n_{n}} q_{i}\left(H_{i}-H_{i}^{*}\right)}{\sum_{m=1}^{n_{0}} Q_{m} H_{m}-\sum_{i=1}^{n_{n}} q_{i} H_{i}^{*}}
$$

Ir seperti yang dituliskan di rumus di atas [9] adalah resilience index dimana qi, $\mathrm{Hi}$ dan $\mathrm{H}^{*}$ secara berturut-turut adalah debit, tekanan eksisting, dan tekanan minimal pada node $i$-th, dan $\mathrm{Qm}$ dan $\mathrm{Hm}$ adalah debit dan tekanan yang diasosiasikan dengan node $m$-th. Semakin tinggi nilai Ir, maka kehilangan energi (energi mengalirkan air di dalam pipa) semakin kecil. Nilai Ir sebelum ada DMA dan sesudah ada DMA dapat saja berubah, perubahan nilai Ir ini dapat dinyatakan dengan persentase pengurangan. Selain menggunakan rumus di atas, 
nilai Ir juga dapat dihitung menggunakan rumus yang lain yaitu [10]:

$$
P_{t}=\frac{\rho \times g \times\left[\left(\sum_{t=1 . t}^{t} Q_{t} \times H_{t}\right)+\left(\sum_{p=1 \ldots p}^{p} Q_{p} \times H_{p}\right)\right]}{1000}
$$

Dimana:

Pt: Tekanan total tangki yang tersedia, $\mathrm{kW}$ $\rho$ : massa jenis air, $1000 \mathrm{~kg} / \mathrm{m}^{3}$

g: percepatan gravitasi, $\mathrm{m}^{2} / \mathrm{s}$

Qt: debit yang keluar dari tanki i, $\mathrm{m}^{3} / \mathrm{s}$

Ht: tekanan total pada tangki i, m

Qp: debit pompa i, $\mathrm{m}^{3} \mathrm{~s}$

Hp: tekanan pompa i, m

$$
P_{n}=\frac{\rho \times g \times\left(\sum_{i=1 \ldots n}^{n} Q_{i} \times H_{i}\right)}{1000}
$$

Dimana:

Pn: tekanan node, $\mathrm{kW}$

$\rho$ : masa jenis air, $1000 \mathrm{~kg} / \mathrm{m} 3$

$\mathrm{g}$ : percepatan gravitasi, $\mathrm{m} 2 / \mathrm{s}$

Qi: debit node i, m3/s

Hi: tekanan total pada node $\mathrm{i}, \mathrm{m}$

$P_{n}^{\text {requiered }}=\frac{\rho \times g \times\left[\sum_{i=1 \ldots n}^{n} Q_{i} \times\left(E_{i}+P_{i}^{\text {requiered }}\right)\right]}{1000}$

Dimana:

Pn required: daya yang dibutuhkan di masing-masing node untuk melayani tekanan minimal, $\mathrm{kW}$

Ei: elevasi pada node i, $\mathrm{m}$

Pi required: tekanan minimal yang dibutuhkan di node i, $\mathrm{m}$

$$
P_{o}=P_{t}-P_{n}
$$

Dimana:

Po: daya yang dibutuhkan untuk beroperasi, $\mathrm{kW}$

Pt: daya yang tersedia, $\mathrm{kW}$

Pn: daya di semua node, Kw

$$
\begin{aligned}
& I r=1-\frac{P_{o}^{\text {real }}}{P_{o}^{\text {requiered }}} \\
& I_{h r}=\left(1-\frac{\sum_{i=1 . \mathrm{n}}^{n} Q_{i}^{x} \times H_{i}^{x}}{\sum_{i=1 . \ldots \mathrm{n}}^{n} Q_{i}^{0} \times H_{i}^{0}}\right) \times 100
\end{aligned}
$$

Indeks pengurangan tekanan/ Index of head reduction [11] dapat digunakan untuk menilai kemampuan sebuah DMA jika terdapat batasan minimal tekanan. Q dan $\mathrm{H}$ berturut-turut adalah debit dan tekanan. $Q_{i}^{x}$ adalah debit pada node i setelah perencanaan DMA. $Q_{i}^{0}$ adalah debit pada node i sebelum perencanaan DMA.

$$
I_{f d}=\frac{\sum_{i=1}^{n} \alpha_{i} Q_{i}}{\sum_{i=1}^{n} Q_{i}}\left\{\begin{array}{c}
Q_{a, i}>Q_{i} \Rightarrow \alpha_{i}=1 \\
0 \leq Q_{a, i} \leq Q_{i} \Rightarrow \alpha_{i}=\frac{Q_{a, i}}{Q_{i}}
\end{array}\right.
$$

Flow deficit index [12]. Indeks ini dikomputasikan menggunakan pendekatan PDA; sedangkan dengan pendekatan demand driven analysis (DDA) besar dari indeks ini selalu bernilai 1. $Q_{a, i}$ adalah debit berdasarkan pendekatan PDA.

Beberapa penelitian menunjukkan bahwa pembentukan DMA dapat mengubah performa hidraulik dari suatu sistem jaringan distribusi air minum. Hal ini tentu dapat menjadi pertimbangan dalam merencanakan DMA. Beberapa perubahan dari performance indices dapat dilihat pada tabel di bawah.

Table 1

Performance Indices Sistem Jaringan Distribusi Air Minum Sebelum (A) dan Sesudah (B) Pembentukan DMA

\begin{tabular}{rrrrrr}
\hline \hline Sumber & $\begin{array}{r}\text { Campbell } \text { et } \\
\text { al., } 2014 \\
\text { [10] }\end{array}$ & $\begin{array}{r}\text { Alvisi, } \\
\text { 2015[12] }\end{array}$ & $\begin{array}{r}\text { Di Nardo } \\
\text { et al., } \\
\text { 2014 [6] }\end{array}$ & $\begin{array}{r}\text { Savic dan } \\
\text { Ferrari, } \\
2014[13]\end{array}$ \\
\hline Ir & A & 0,24 & 0,61 & & 0,84 \\
& B & 0,23 & 0,59 & & 0,81
\end{tabular}

Ird $(\%)$

$12 \%$

Ihr $(\%)$

$1,61 \%$

$\operatorname{Pmaks}(\mathrm{m}) \quad \mathrm{A}$

98,53

B

98,27

Prata-rata A 38,57

(m)

B 27,03

$\operatorname{Pmin}(\mathrm{m}) \quad \mathrm{A}$

B

26,8

$26,5 \quad 20,95$

Water age A

30,71

(jam)

B

31,62

A: sebelum ada DMA

B: sesudah ada DMA

\section{Algoritma Pembentukan DMA}

Beberapa penelitian yang telah digunakan untuk membentuk DMA menggunakan metode/ algoritma graph clustering, spectral clustering, community detection, multi agent system, breadth first search, depth first search, multilevel partitioning, multilevel recursive bisection, genetic algorithm.

Setiap penulis tidak hanya mempunyai algoritma yang berbeda-beda, namun juga mempunyai tahapan dan aturanaturan dalam pemilihan area pembentukan DMA yang berbeda pula. Secara umum dapat diketahui bahwa langkah-langkah dalam pemilihan area pembentukan DMA meliputi:

1) Mengetahui/ memastikan bahwa kondisi hidrolika sistem jaringan distribusi sudah baik; kecepatan, tekanan minimal, dan headlossnya sudah sesuai standar,

2) Memisahkan pipa primer dari proses awal pengklusterisasian sistem jaringan distribusi, 
1) Menentukan/ tidak menentukan batasan ukuran jumlah sambungan rumah/ koneksi pelanggan yang ada dalam tiap DMA,

2) Menentukan metode algoritma yang dipilih untuk pengklusterisasian beserta bobotnya,

3) Menentukan/ tidak menentukan fungsi objektif yang ingin dimasukkan,

4) Menjalankan simulasi, dimulai dari mengubah format epanet ke algoritma yang dipilih kemudian menjalankan file yang telah diubah di program yang dapat menjalankan algoritma yang dipilih,

5) Mengevaluasi sistem jaringan distribusi setelah DMA terbentuk menggunakan index.

Beberapa penulis memasukkan optimisasi sebagai salah satu langkah dalam merencanakan DMA. Konsep optimisasi sekarang dikenal sebagai dasar untuk menganalisis dan menyelesaikan permasalahan yang kompleks dan banyak. Optimisasi memberikan penyelesaian untuk permasalahan yang komplek. Penyelesaian tersebut dipengaruhi variabelvariabel yang mempengaruhinya [14] (Luenberger dan Ye, 2008). Sebuah permasalahan optimasi (optimization problem), yang dimodelkan secara matematis, umumnya terdiri dari fungsi-fungsi tujuan (objective functions) dan kendala-kendala (constraints). Fungsi tujuan merepresentasikan tujuan yang ingin dioptimalkan [15] (Mahmudy dan Rahman, 2011). Jika dirangkum berdasarkan kelebihan dan kekurangan masingmasing metode yang digunakan oleh penulis maka dapat dilihat seperti tampak pada tabel di bawah.

Table 2.

Algoritma Pembentukan DMA

\begin{tabular}{|c|c|c|c|c|}
\hline Penulis & $\begin{array}{l}\text { Algoritma } \\
\text { yang } \\
\text { digunakan }\end{array}$ & $\begin{array}{l}\text { Indikator } \\
\text { Pembandi } \\
\text { ng } \\
\text { (sebelum- } \\
\text { sesudah) }\end{array}$ & $\begin{array}{l}\text { Faktor } \\
\text { Finansial }\end{array}$ & $\begin{array}{l}\text { Ukuran } \\
\text { DMA }\end{array}$ \\
\hline $\begin{array}{l}\text { Alvisi } \\
\text { dan atau } \\
\text { Franchin } \\
\text { i }\end{array}$ & $\begin{array}{l}\text { Breadth } \\
\text { First } \\
\text { Search, } \\
\text { Multilevel } \\
\text { Balancing } \\
\text { and } \\
\text { Refinement } \\
{[12][16]}\end{array}$ & $\begin{array}{l}\text { Resilience } \\
\text { Index dan } \\
\text { Tekanan }\end{array}$ & $\begin{array}{l}\text { Pertimbangan } \\
\text { biaya yang } \\
\text { berbanding } \\
\text { lurus dengan } \\
\text { semakin } \\
\text { besarnya } \\
\text { diameter }\end{array}$ & Ada \\
\hline $\begin{array}{l}\text { Campbel } \\
1\end{array}$ & $\begin{array}{l}\text { Social } \\
\text { network, } \\
\text { community } \\
\text { detection, } \\
\text { Label } \\
\text { Propagation } \\
{[10]}\end{array}$ & $\begin{array}{l}\text { Resilience } \\
\text { Index dan } \\
\text { Tekanan }\end{array}$ & $\begin{array}{l}\text { Optimasi } \\
\text { biaya } \\
\text { pemasangan } \\
\text { valve, meter } \\
\text { air, dan air } \\
\text { yang dapat } \\
\text { disimpan } \\
\text { karena } \\
\text { kontrol } \\
\text { tekanan }\end{array}$ & Ada \\
\hline
\end{tabular}

Lanjutan Tabel 2.

\begin{tabular}{|c|c|c|c|c|}
\hline Penulis & $\begin{array}{l}\text { Algoritma } \\
\text { yang } \\
\text { digunakan }\end{array}$ & $\begin{array}{l}\text { Indikator } \\
\text { Pembanding } \\
\text { (sebelum- } \\
\text { sesudah) }\end{array}$ & $\begin{array}{l}\text { Faktor } \\
\text { Finansial }\end{array}$ & $\begin{array}{l}\text { Ukuran } \\
\text { DMA }\end{array}$ \\
\hline $\begin{array}{l}\text { De Paola } \\
\text { et al. }\end{array}$ & 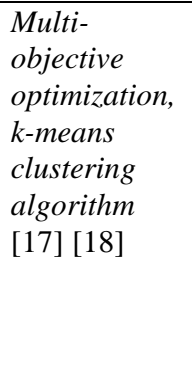 & $\begin{array}{l}\text { Resilience } \\
\text { Index }\end{array}$ & $\begin{array}{l}\text { Optimasi } \\
\text { biaya } \\
\text { pemasangan } \\
\text { valve, energi } \\
\text { yang hilang } \\
\text { karena } \\
\text { kebocoran, } \\
\text { dan } \\
\text { discounting } \\
\text { rate }\end{array}$ & Ada \\
\hline $\begin{array}{l}\text { Di Nardo } \\
\text { et al. }\end{array}$ & $\begin{array}{l}\text { Multilevel } \\
\text { Recursive } \\
\text { Bisection, } \\
\text { Multi Agent, } \\
\text { Edge } \\
\text { Betweenness } \\
\text { Community, } \\
\text { Fast Greedy } \\
\text { Community, } \\
\text { Ant } \\
\text { Algorithm } \\
{[19][20]} \\
{[21]}\end{array}$ & $\begin{array}{l}\text { Resilience } \\
\text { Index, flow } \\
\text { deficit index } \\
\text { dan Tekanan }\end{array}$ & Tidak ada & Ada \\
\hline $\begin{array}{l}\text { Diao et } \\
\text { al. }\end{array}$ & $\begin{array}{l}\text { Community } \\
\text { Structure } \\
{[22]}\end{array}$ & Tidak ada & Tidak ada & Tidak \\
\hline $\begin{array}{l}\text { Ferrari et } \\
\text { al. }\end{array}$ & $\begin{array}{l}\text { Breadth } \\
\text { First Search } \\
{[23]}\end{array}$ & Tidak ada & Tidak ada & Ada \\
\hline Galdiero & $\begin{array}{l}\text { Multi- } \\
\text { Objective } \\
\text { Evolutionary } \\
\text { Algorithm } \\
{[24]}\end{array}$ & $\begin{array}{l}\text { Resilience } \\
\text { index }\end{array}$ & $\begin{array}{l}\text { Biaya } \\
\text { Kehilangan } \\
\text { air, biaya } \\
\text { konstruksi, } \\
\text { dan } \\
\text { discounting } \\
\text { rate }\end{array}$ & Ada \\
\hline $\begin{array}{l}\text { Giustolisi } \\
\text { dan } \\
\text { Ridolfi }\end{array}$ & $\begin{array}{l}\text { Modularity } \\
{[25]}\end{array}$ & Tidak ada & Tidak ada & Tidak \\
\hline $\begin{array}{l}\text { Gomes et } \\
\text { al. }\end{array}$ & $\begin{array}{l}\text { Floyd- } \\
\text { Warshall } \\
\text { Algorithm } \\
\text { dan } \\
\text { Simulated } \\
\text { Annealing } \\
{[26]}\end{array}$ & Tidak ada & $\begin{array}{l}\text { Optimasi } \\
\text { biaya } \\
\text { pemasangan } \\
\text { valve, meter } \\
\text { air, dan pipa } \\
\text { yang diganti }\end{array}$ & Ada \\
\hline $\begin{array}{l}\text { Hajebi et } \\
\text { al. }\end{array}$ & $\begin{array}{l}\text { K-means } \\
\text { algorithm, } \\
\text { Multi Agent } \\
\text { System, } \\
\text { Graph } \\
\text { Partitioning, } \\
\text { NSGA-II. } \\
{[27]}\end{array}$ & Tidak ada & $\begin{array}{l}\text { Optimasi } \\
\text { biaya } \\
\text { pemasangan } \\
\text { valve, meter } \\
\text { air, dan pipa } \\
\text { yang diganti }\end{array}$ & Ada \\
\hline
\end{tabular}


Lanjutan Tabel 2.

\begin{tabular}{|c|c|c|c|c|}
\hline Penulis & $\begin{array}{l}\text { Algoritma } \\
\text { yang } \\
\text { digunakan }\end{array}$ & $\begin{array}{l}\text { Indikator } \\
\text { Pembanding } \\
\text { (sebelum- } \\
\text { sesudah) }\end{array}$ & $\begin{array}{l}\text { Faktor } \\
\text { Finansial }\end{array}$ & $\begin{array}{l}\text { Ukuran } \\
\text { DMA }\end{array}$ \\
\hline Herrera & $\begin{array}{l}\text { Multi agent } \\
\text { system, } K- \\
\text { shortest path } \\
{[28]}\end{array}$ & Tidak ada & Tidak ada & \\
\hline $\begin{array}{l}\text { Izquierdo } \\
\text { et al. }\end{array}$ & $\begin{array}{l}\text { Multi Agent } \\
\text { System [29] }\end{array}$ & Tidak ada & Tidak ada & Ada \\
\hline $\begin{array}{l}\text { Perelman } \\
\text { et al. }\end{array}$ & $\begin{array}{l}\text { Graph } \\
\text { Clustering, } \\
\text { Community } \\
\text { Structure, } \\
\text { Graph } \\
\text { Partitioning, } \\
\text { Greedy } \\
\text { Algorithm } \\
{[30]}\end{array}$ & Tidak ada & Tidak ada & Ada \\
\hline $\begin{array}{l}\text { Savic } \\
\text { dan } \\
\text { Ferrari }\end{array}$ & $\begin{array}{l}\text { Breadth first } \\
\text { search [31] }\end{array}$ & $\begin{array}{l}\text { Resilience } \\
\text { index dan } \\
\text { water age }\end{array}$ & Tidak ada & Ada \\
\hline $\begin{array}{l}\text { Scibetta } \\
\text { et al. }\end{array}$ & $\begin{array}{l}\text { Fast- } \\
\text { greeding } \\
\text { algorithm } \\
{[32]}\end{array}$ & Tidak ada & Tidak ada & Tidak \\
\hline
\end{tabular}

\section{STUDI KASUS}

Berdasarkan rencana peletakan meter air, gate valve, boundary valve, dan aksesoris lainnya yang direncanakan di subbab-subbab sebelumnya, maka dapat dihitung besarnya biaya untuk membangun DMA sesuai dengan tabel di bawah.

Table 3.

RAB dan BOQ Perencanaan DMA

\begin{tabular}{|c|c|c|c|c|c|}
\hline No & $\begin{array}{l}\text { Uraian } \\
\text { Pekerjaan }\end{array}$ & $\begin{array}{l}\text { Sat } \\
\text { uan }\end{array}$ & $\begin{array}{l}\text { Vol } \\
\text { ume }\end{array}$ & $\begin{array}{l}\text { Harga } \\
\text { Satuan } \\
\text { (Rupiah) }\end{array}$ & $\begin{array}{l}\text { Harga } \\
\text { (Rupiah) }\end{array}$ \\
\hline 1 & $\begin{array}{l}\text { Pembersihan } \\
\text { lapangan berat }\end{array}$ & $m^{2}$ & 24 & $15.900^{1}$ & 381.600 \\
\hline 2 & $\begin{array}{l}\text { Penggalian } \\
\text { Tanah }\end{array}$ & $m^{3}$ & 36 & $77.250^{1}$ & 2.781 .000 \\
\hline 3 & $\begin{array}{l}\text { Pemotongan } \\
\text { pipa }\end{array}$ & $\mathrm{m}^{\prime}$ & 12 & $169.074^{1}$ & 2.028 .888 \\
\hline 4 & $\begin{array}{l}\text { Pengadaan dan } \\
\text { Pemasangan } \\
\text { Gate Valve } 100 \\
\text { mm }\end{array}$ & $\begin{array}{l}\mathrm{Bu} \\
\mathrm{ah}\end{array}$ & 4 & $\begin{array}{r}1.779 .600 \\
2\end{array}$ & 7.118 .400 \\
\hline 5 & $\begin{array}{l}\text { Pengadaan dan } \\
\text { Pemasangan } \\
\text { Butterfly Valve } \\
150 \mathrm{~mm}\end{array}$ & $\begin{array}{l}\mathrm{Bu} \\
\mathrm{ah}\end{array}$ & 5 & $\begin{array}{r}3.706 .600 \\
2\end{array}$ & 18.533 .000 \\
\hline 6 & $\begin{array}{l}\text { Pengadaan dan } \\
\text { Pemasangan } \\
\text { Butterfly Valve } \\
100 \mathrm{~mm}\end{array}$ & $\begin{array}{l}\mathrm{Bu} \\
\mathrm{ah}\end{array}$ & 2 & $\begin{array}{r}3.088 .000 \\
2\end{array}$ & 6.176 .000 \\
\hline 7 & $\begin{array}{l}\text { Pengadaan } \\
\text { Elbow } 100 \mathrm{~mm}\end{array}$ & $\begin{array}{l}\mathrm{Bu} \\
\mathrm{ah}\end{array}$ & 2 & $46.260^{2}$ & 92.250 \\
\hline
\end{tabular}

Lanjutan Tabel 3.

\begin{tabular}{|c|c|c|c|c|c|}
\hline No & $\begin{array}{l}\text { Uraian } \\
\text { Pekerjaan }\end{array}$ & $\begin{array}{l}\text { Sat } \\
\text { uan }\end{array}$ & $\begin{array}{l}\text { Vol } \\
\text { ume }\end{array}$ & $\begin{array}{l}\text { Harga } \\
\text { Satuan } \\
\text { (Rupiah) }\end{array}$ & $\begin{array}{l}\text { Harga } \\
\text { (Rupiah) }\end{array}$ \\
\hline 8 & $\begin{array}{l}\text { Pengadaan } \\
\text { dan } \\
\text { Pemasanga }\end{array}$ & $\begin{array}{l}\mathrm{Bu} \\
\mathrm{ah}\end{array}$ & 1 & $\begin{array}{r}100.000 .0 \\
00^{2}\end{array}$ & 100.000 .000 \\
\hline & $\begin{array}{lr}n & \text { Meter } \\
\text { Air } & 100 \\
\text { mm } & \end{array}$ & & & & \\
\hline 9 & $\begin{array}{l}\text { Penguruga } \\
\text { n tanah } \\
\text { dengan } \\
\text { pemadatan } \\
\text { bahan }\end{array}$ & $m^{a}$ & 36 & $211.900^{1}$ & 7.628 .400 \\
\hline 10 & $\begin{array}{l}\text { Pengerjaan } \\
\text { Thrust } \\
\text { Block }\end{array}$ & $m^{a}$ & 0,18 & 598.400 & 107.712 \\
\hline 11 & & & & Total RAB & 132.537 .362 \\
\hline
\end{tabular}

Besarnya biaya yang dibutuhkan untuk merencanakan DMA dan valve untuk flow step testing pada Perumahan Rungkut Mapan Permai, Barat, dan Tengah yang melayani 1.376 sambungan rumah (diperkirakan 5 orang tiap sambungan rumah) adalah sebanyak Rp. 132.537.362 (Seratus Tiga Puluh Dua Juta Lima Ratus Tiga Puluh Tujuh Tiga Ratus Enam Puluh Dua Rupiah).

\section{KESIMPULAN DAN RINGKASAN}

Cara merencanakan DMA secara berturut-turut adalah menyiapkan peta jaringan, menetapkan rentang jumlah, membentuk DMA sesuai dengan rentang jumlah, menutup/ membuat valve batas, memastikan DMA sudah terisolasi, dan melakukan pemasangan meter air. Pembentukan DMA di suatu jaringan distribusi air minum yang sudah ada memerlukan peralatan berupa valve-valve, meter air, dan aksesorisnya.

Hal-hal yang dijadikan sebagai faktor penilaian baik/ tidaknya DMA yang sudah terbentuk meliputi resilience index, tekanan, flow deficit index, dan water age.

Algoritma/ prosedur dalam merencanakan DMA dapat menggunakan satu atau kombinasi dari beberapa algoritma. Algoritma untuk mendesain DMA dapat berupa algoritma partitioning, sectorization, clustering, dan community detection. Algoritma yang dapat digunakan untuk merencanakan DMA meliputi algoritma Ant Algorithm, Breadth First Search, Community Structure, Edge Betweenness Community, Floyd-Warshall Algorithm, Graph clustering, Graph Partitioning, K-means algorithm, K-shortest path, Label Propagation, Multi Agent System, Modularity, NSGA II (Non-dominated sorting genetic algorithm), Simulated Annealing, Social network theory. Perencanaan DMA dapat menggunakan algoritma dengan pertimbangan biaya konstruksi, kehilangan uang karena air yang hilang, discounting rate. 


\section{UCAPAN TERIMA KASIH}

Penulis mengucapkan terimakasih kepada PDAM Surya Sembada terutama Bagian PKA (Pengendalian Kehilangan Air) atas informasi yang memperluas wawasan bagi penulis mengenai implementasi pembentukan DMA. Penulis juga mengucapkan terimakasih kepada Pemerintah Indonesia atas Beasiswa PPA BBM dan Yayasan Karya Salemba Empat atas Beasiswa KSE yang pernah diberikan kepada penulis.

\section{DAFTAR PUSTAKA}

[1] A. Lambert, B. Charalambous, M. Fantozzi, J. Kovač, A. Rizzo dan S. "14 Years' Experience of using IWA Best Practice Water Balance and Water Loss Performance Indicators in Europe". Vienna, Austria, 1st April 2014, IWA Water Loss (2014).

[2] Badan Pendukung Pengembangan Sistem Penyediaan Air Minum, Kinerja PDAM 2014 Wilayah II (Pulau Jawa). Jakarta: Kementerian Pekerjaan Umum dan Perumahan Rakyat (2014).

[3] M. Farley, dan R. Liemberger. "Developing a Non-Revenue Water reduction strategy: Planning and implementing the strategy". Water Supply, 5(1), 41-50 (2005).

[4] M. Farley, G. Wyeth, Z. Bin Md. Ghazali, A. Istandar, S. Singh, Buku Pegangan tentang Air Tak Berekening (NRW) untuk Manajer: Panduan untuk Memahami Kehilangan Air. Jakarta: Direktorat Jenderal Cipta Karya PU (2008).

[5] J. Morrison, S. Tooms, D. Rogers, District Metered Areas: Guidance Notes version 1. Water Loss Management: International Water Association (2007).

[6] A. Di Nardo, M. Di Natale, G. F. Santonastaso, V. G. Tzatchkov, V. H. Alcocer-Yamanaka, "Water network sectorization based on graph theory and energy performance indices," Journal of Water Resource Planning and Management, Vol. 140, No. 5, (2014).

[7] J. Izquierdo, M. Herrera, L. Montalvo, Perez-Garcia, "Division of Water Supply Systems into District Metered Areas Using a Multi-Agent Based Approach," Sotware and Data Technologies, pp. 167 - 180, (2011).

[8] R. Gomes, J. Sousa, A. Sá Marques, "Influence of future water demand patterns on the district metered area areas design and benefits yielded by pressure management," Procedia Engineering, Vol 70: 744 - 752, (2014).

[9] E. Todini, "Looped Water Distribution Networks Design Using a Resilience index based heuristic approach," Journal of Urban Water, Vol 2: 115-122 (2000).

[10] E. Campbell, D. Ayala-Cabrera, J. Izquierdo, R. Perez-Garcia, "Water Supply Network Sectorization Based on social networks community detection algorithms," Procedia Engineering, Vol 89, 1208 - 1215 (2014).

[11] Di Nardo A, Di Natale M, "A heuristic design support methodology based on graph theory for district metering of water supply networks" Eng Optim, 43(2):193-211 (2011).

[12] S. Alvisi, "A New Procedure for Optimal Design of District Metered Area Based on the Multilevel Balancing and Refinement," Water Resour Management, Vol. 29: 4397-4409 (2015).

[13] D. Savic, and G. Ferrari, "Design and performance of district metering areas in water distribution system," Procedia Engineering, Vol. 89: 1136 - 1143 (2014).

[14] D. G. Luenberger and Y. Ye, Linear and Nonlinear Programming. Springer Science: Stanford, (2008).

[15] W. F. Mahmudy, M. A. Rahman, "Optimasi Fungsi Multi-Obyektif Berkendala Menggunakan Algoritma Genetika Adaptif Dengan Pengkodean Real," Jurnal Ilmiah KURSOR, Vol. 6, No 1: 19-26 (2011).

[16] S. Alvisi dan M. Franchini, "A procedure for the design of district metered areas in water distribution systems," Procedia Engineering, Vol. 70: 41 - 50, (2014).

[17] F. De Paola, N. Fontana, E. Galdiero, M. Giugni, D. Savix, G. Soregenti, "Automatic Multi-Objective Sectorization of a Water Distribution Network," Procedia Engineering, Vol. 89: 1200 - 1207 (2014).

[18] F. De Paola, N. Fontana, E. Galdiero, M. Giugni, Soregenti, G. M. Vitaletti, "Optimal Design of District Metered Areas in Water
Distribution Networks," Procedia Engineering, Vol. 70: 449 - 4457, (2014).

[19] A. Di Nardo, M. Di Natale, C. Giudicianni, D. Musmarra, G. F. Santonastaso, A. Simone, "Water distribution system clustering ant partitioning based on social network algorithms," Procedia Engineering, Vol. 119: 196 - 205 (2015).

[20] A Di Nardo, M. Di Natale, R. Greco, G.F. Santonastaso, "Ant algorithm for smart water network partitioning," Procedia Engineering, Vol. 70: $525-534$, (2014).

[21] A. Di Nardo, M. Di Natale, G. F. Santonastaso, V. G. Tzatchkov, V.H. Alcocer-Yamanaka, "Water network sectorization based on graph theory and energy performance indices," Journal of Water Resource Planning and Management, Vol. 140, No. 5 (2014).

[22] K. Diao, Y. Zhou, W. Rauch, "Automated Creation of District Metered Area Boundaries in Water Distribution Systems," Journal of Water Resource Planning and Management, Vol. 140: 184-190 (2013).

[23] G. Ferrari, D. Savic, dan G. Becciu, "Graph - Theoretic Approach and Sound Engineering Principles for Design of District Metered Areas," $J$. Water Resour. Plann. Management, Vol. 140: 12, (2014).

[24] E. Galdiero, "Multi-Objective Design of District Metered Areas in Water Distribution," Ph. D Thesis, Dipartimento di Ingegneria Civile, Edile ed Ambientale Networks, Universita Degu Studi Di Napoli Federico II, (2015).

[25] O. Giustolisi, and L. Ridolfi, "Modularity Index for The Segmentation of Water Distribution Networks," International Conference on Hydroinformatics, Paper 148 (2014).

[26] R. Gomes, J. Sousa, J. Muranho, A. S. Marques, "Differrent Design Criteria for District Metered Areas in Water Distribution Networks," Procedia Engineering, Vol. 119: 1221 - 1230 (2015).

[27] S. Hajebi, S. Barrett, A. Clarke, S. Clarke, "Multi-agent simulation to support water distribution network partitioning," Conference Paper, In 27th European Simulation and Modelling Conference - ESM'2013.

[28] S. Hajebi, S. Temate, S. Barett, A. Clarke, and S. Clarke, "Water Distribution Network Sectorization Using Structural Graph Partitioning and Multi-Objective Optimization," Procedia Engineering, Vol. 89: 1144 - 1151, (2014).

[29] M. Herrera, "Improving water network management by efficient division into supply clusters," Ph. D Thesis, Departamento de Ingineria Hidraulica y Medio Ambiente, Universitat Politecnica De Valencia, Valencia (2011).

[30] J. Izquierdo, M. Herrera, I. Montalvo, I. Perez-Garcia, "Division of Water Supply Systems into District Metered Areas Using a Multi-Agent Based Approach," Software and Data Technologies, pp. 167 - 180 2011.

[31] L. S. Perelman, M. Allen, A. Preis, M. Iqbal, and A. J. Whittle, "Multilevel automated sub-zoning of water distribution systems". International Environmental Modelling and Software Society (iEMSs) 7th Intl (2014).

[32] M. Scibetta, F. Boano, R. Revellia, and L. Ridolfi, "Community detection as a tool for district metered areas identification," Procedia Engineering, Vol. 70: 1518 - 1523 (2014). 